\title{
Effect of Fermentation Using Lactobacillus plantarum A6 on the Physicochemical and Functional Properties of Precooked Sorghum bicolor and Voandzeia subterranea Blended Flour
}

\author{
Thierry Marcel Beumo Ntsamo, ${ }^{1}$ Bouba Adji Mohammadou, ${ }^{2}$ Alphonse Tegang Sokamte, ${ }^{1}$ \\ Nicolas Yanou Njintang, ${ }^{3}$ and Leopold Ngoune Tatsadjieu ( ${ }^{2}{ }^{2}$ \\ ${ }^{1}$ National School of Agro-Industrial Sciences, Department of Food Science and Nutrition, University of Ngaoundere, P.O. Box 455, \\ Ngaoundere, Cameroon \\ ${ }^{2}$ University Institute of Technology, Department of Food Engineering and Quality Control, University of Ngaoundere, \\ P.O. Box 454 Ngaoundere, Cameroon \\ ${ }^{3}$ Faculty of Sciences, Department of Biological Sciences, University of Ngaoundere, P.O. Box 454, Ngaoundere, Cameroon
}

Correspondence should be addressed to Leopold Ngoune Tatsadjieu; tatsadjieu@yahoo.fr

Received 12 February 2020; Revised 9 November 2020; Accepted 26 November 2020; Published 10 December 2020

Academic Editor: Giorgia Spigno

Copyright (c) 2020 Thierry Marcel Beumo Ntsamo et al. This is an open access article distributed under the Creative Commons Attribution License, which permits unrestricted use, distribution, and reproduction in any medium, provided the original work is properly cited.

\begin{abstract}
The present study is aimed at producing Sorghum bicolor and Voandzeia subterranea complementary instant flour. The precooked sorghum and Bambara groundnut flours were mixed at different proportions $(0: 100,25: 75,50: 50,75: 25$, and $100: 0)$, hydrated with sterile distilled water $(1: 3, \mathrm{w}: \mathrm{v})$, and fermented for $72 \mathrm{~h} / 37^{\circ} \mathrm{C}$ using Lactobacillus plantarum A6 at $10^{5} \mathrm{CFU} / \mathrm{g}$. During the fermentation, samples were withdrawn for $\mathrm{pH}$, titrable acidity, and microbial analyses. After fermentation, color, particle size, water absorption capacity (WAC), solubility index, least gelling concentration (LGC), and physicochemical and pasting properties were determined. The results showed that the fermentation significantly $(p \leq 0.05)$ decreased WAC, LGC, peak viscosity, final viscosity, breakdown, and $\mathrm{pH}$, but increased the solubility index and titrable acidity of flours. The protein and carbohydrates contents as well as the color, particle size, and the setback after the cooking of the flour were not significantly affected by the fermentation. The flours ratio and fermentation also significantly decreased the total polyphenols, tannins, and phytate content of the samples. The fermented blended flour containing $25 \%$ precooked sorghum flour and $75 \%$ roasted Bambara flour (SVFP25) is a promising alternative as instant flour used for young children's nutrition.
\end{abstract}

\section{Introduction}

More than 200 million children under five around the world are malnourished [1] and living mainly in developing countries. This is mainly due to the poor dietary practices and low nutritional quality of food used for infants' and children's nutrition. Indeed, to ensure adequate infant feeding, exclusive breastfeeding from birth to 6 months as well as adequate complementary feeding introduced from 6 months up to 24 months or more with continued breastfeeding is recommended [2]. Complementary food is food used for infant feeding along with breast milk feeding when breast milk alone is no longer sufficient to meet all nutritional require- ments [3]. It should have about $92-95 \%$ of dry matter, $68 \%$ of carbohydrates, $15 \%$ of proteins, $8 \%$ of lipids, $3.2 \%$ of fibers, $2.9 \%$ of ash, and a caloric value of about $400 \mathrm{kcal} / 100 \mathrm{~g}$ [4]. In Africa, starchy flours from tubers or cereals are generally used as raw material by local populations to prepare gruels used as a complementary food for infant nutrition. However, these gruels due to their high viscosity, low energy density $(20-40 \mathrm{kcal} / 100 \mathrm{~mL})$, and nutritional quality [5] are inappropriate for the young child feeding. The high viscosity of these gruels is due to the gelatinization of the native starch during cooking.

To reduce this viscosity and increase the energy density of the gruels, the partial hydrolysis of starch in flour before, 
during, and after the production of flour by thermal [6] or enzymatic modification (germination, use of amylase, fermentation with amylolytic microorganisms) have been proposed $[7,8]$. Beyond the starch hydrolysis, the fermentation of starchy products using selected microorganisms like lactic acid bacteria (LAB) improves the nutritional and sensory values, as well as microbiological safety of the final products $[9,10]$. LAB are able to ferment different types of starchy products such as corn, potatoes, and millet $[11,12]$. Judiciously selected, a pure strain of amylolytic lactic acid bacteria use for fermentation could allow the production of fluid gruel with high energy density. However, it has been shown that additional treatments such as cooking and roasting can be applied prior to the fermentation of starchy raw materials in order to obtain a fluid slurry with a much-improved energy density, as well as better nutritional quality. For instance, Haydersah et al. [13] show that when Lactobacillus plantarum is used to ferment the precooked starch, there is a greater decrease in the viscosity compared to native starch of the resulting porridge, and consequently a better increase in its energy density. Furthermore, the use of leguminous seeds during this flour preparation can allow improving its nutritional value, mainly the protein content and protein quality.

Sorgum (Sorghum bicolor L. Moench) and Bambara groundnut (Voandzeia subterranea L. Thouars) are two indigenous crops of tropical Africa widely cultivated for their seeds used as foodstuff. The annual production of sorghum in Africa is estimated at around 20 million tons, and it has the advantage of tolerating adverse conditions such as hot, dry, wet, and water-logged conditions [14]. Its grains contain mainly carbohydrates $(77 \%)$, proteins $(11 \%)$, and lipids (3\%) [15]. Bambara groundnut is the third important leguminous after groundnut and cowpea in Africa [16]. In Cameroon, its production was estimated in 2013 at 36,639 tons [17]. It can grow on low fertile soils of dry regions and tolerate fairly acidic soils [18]. Its seeds have high nutritional value with high protein content (19-28\%), are highly caloric (about $387 \mathrm{kcal} / 100 \mathrm{~g}$ ), and are rich in several minerals (magnesium, calcium, iron, manganese, sodium, potassium) and vitamins (thiamine, riboflavin, niacin, pantothenic, ascorbic acid, pyrodoxine, alpha-tocopherol, and vitamin K) [1921]. Because of its nutritional and technological potential, the Bambara groundnut has been found to be a good leguminous crop to enrich the protein content of a maize-based pudding (abari) [22]. However, to the best of our knowledge, and despite the nutritional and technological potential of sorghum and Bambara seeds, the valorization of their seeds as the main raw material in the production of infant food flour has not been the subject of any published scientific study.

The aim of this study was to evaluate the effect of combining heat treatments and fermentation with Lactobacillus plantarum A6 strain on the quality of an instant flour food made with sorghum and Bambara groundnut flours as raw materials.

\section{Materials and Methods}

2.1. Raw Material. The dry sorghum grains of madjeru variety and dry white Bambara groundnut were purchased from local markets in Ngaoundere (Adamaoua region, Cameroon) in June 2018.

2.2. Stater. Lactobacillus plantarum A6 strain used for the fermentation was provided by the Microbiology Laboratory of CIRAD Montpellier, France.

2.3. Production of Precooked Flours. The precooked flours were produced as shown in Figure 1. Sorghum grains were sorted manually to remove stones and other impurities. The clean seeds were then soaked $(1: 3, \mathrm{w}: \mathrm{v})$ in a solution of $\mathrm{Ca}(\mathrm{OH})_{2}(1.5 \mathrm{~g} / \mathrm{L})$ at $50^{\circ} \mathrm{C}$ for $20 \mathrm{~min}$ in the water-batch, then removed and maintained at room temperature $\left(25 \pm 2^{\circ} \mathrm{C}\right)$ for $10 \mathrm{~h}$ and manually dehulled. The dehulled grains were then precooked at $121^{\circ} \mathrm{C} / 15 \mathrm{~min}$ in the autoclave (Caudice Civab Autosa 76, Roma, Italy), drained, and cooled at room temperature on stainless trays and dried at $45^{\circ} \mathrm{C}$ for $24 \mathrm{~h}$ in a ventilated electric dryer (Riviera and Bar, France). The dried cooked grains were ground in a hammer mill (Culatti, polymix, France) fitted with a $500 \mu \mathrm{m}$ pore size sieve.

Bambara seeds were manually cleaned thoroughly, and foreign materials as well as broken and immature seeds were removed. The clean seeds were soaked in distilled water $(1: 3$, $\mathrm{w}: \mathrm{v})$ at $60^{\circ} \mathrm{C}$ for $8 \mathrm{~h}$, drained on stainless trays, and dried at $60^{\circ} \mathrm{C}$ for $12 \mathrm{~h}$ in the oven. The dried seeds were dehulled by abrasion using hand millstone and winnowing, roasted in a laboratory roaster (Torre Picenardi, PANACEA 430, Italy) at $140^{\circ} \mathrm{C}$ for $30 \mathrm{~min}$, cooled at room temperature, and milled with a hammer mill (Culatti, polymix, France) fitted with a $500 \mu \mathrm{m}$ pore size sieve. The different flours produced were sealed in high-density polyethylene bags and stored in a dry condition at laboratory temperature for further uses and analyses.

Mixtures of precooked sorghum and Bambara groundnut flours were formulated using different proportions $0: 100$, $25: 75,50: 50,75: 25$, and 100:0 (sorghum:Bambara groundnut, w:w).

\subsection{Fermentation of Blended Flours}

2.4.1. Cultivation of Lactobacillus plantarum A6. The stock culture of $L b$. plantarum A6 used was precultured in Man Rogosa Sharp (MRS: yeast extract: $5 \mathrm{~g}$; meat extract: $5 \mathrm{~g}$; peptone: $10 \mathrm{~g}$; sodium acetate: $5 \mathrm{~g}$; sodium citrate: $2 \mathrm{~g}$; glucose: $20 \mathrm{~g}$; potassium phosphate: $2 \mathrm{~g}$; magnesium sulphate: $0.1 \mathrm{~g}$; manganese sulphate: $0.05 \mathrm{~g}$; tween: $1 \mathrm{~mL}$ ) broth at $37^{\circ} \mathrm{C}$ for $24 \mathrm{~h}$. After this period, the volume of the broth was completed to $1 \mathrm{~L}$ under aseptic conditions with sterile MRS broth, homogenized, and incubated at $37^{\circ} \mathrm{C}$ for $16 \mathrm{~h}$. The resulting culture broth was centrifuged (Hereaus Biofuge primo R, Germany) at $6500 \mathrm{rpm}$ at $4^{\circ} \mathrm{C}$ for 20 minutes. The bottom was collected, washed thrice with sterile saline water $(8.5 \mathrm{~g} / \mathrm{L} \mathrm{NaCl})$, and used to prepare inoculum.

2.4.2. Inoculation and Fermentation. For fermentation, $500 \mathrm{~g}$ of the samples from each flour and mixture were introduced into $2500 \mathrm{~mL}$ glass bottle and autoclaved at $121^{\circ} \mathrm{C}$ for $15 \mathrm{~min}$. After cooling at room temperature in aseptic conditions, each flour was hydrated using sterile distilled water $(1: 3, \mathrm{w}: \mathrm{v})$. 


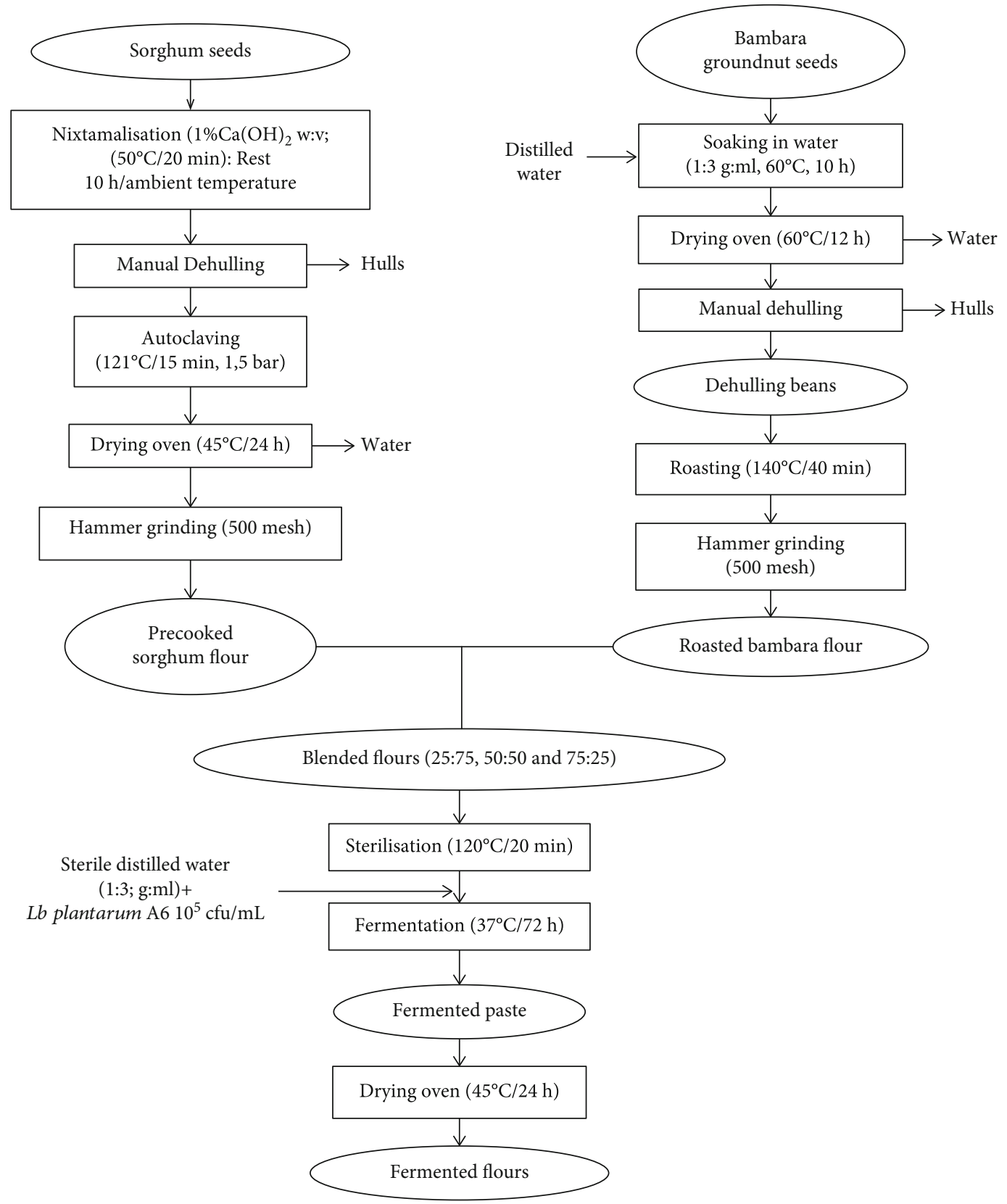

Figure 1: Flow diagram for the production of sorghum and Bambara groundnut precooked and fermented flours.

The slurry obtained was inoculated with $3 \mathrm{~mL}$ of suspension of $L b$. plantarum A6 to achieve a final concentration of $10^{5} \mathrm{CFU} / \mathrm{g}$, then homogenized aseptically with a sterile glass rod and incubated at $37^{\circ} \mathrm{C}$ for $72 \mathrm{~h}$.

2.5. Microbial Count and Chemical Analysis during Fermentation. During fermentation, the samples were withdrawn at $0,2,4,6,8,12,16,20,32,44,56$, and $72 \mathrm{~h}$. Before drying, the $\mathrm{pH}$, titrable acidity, and microbial count of the samples were determined. The $\mathrm{pH}$ of the sample was measured by introducing the glass electrode of the $\mathrm{pH}$ meter into the sample [23]. The titrable acidity was measured using the method described by AOAC [24]. Ten milliliters of the sample slurries was titrated using $0.1 \mathrm{M} \mathrm{NaOH}$ with phenol- phthalein as an indicator. The amount of acid produced was expressed as a percentage of equivalent lactic acid. The Lb. plantarum A6 count of the fermented samples was determined according to the modified method described by Leclerc et al. [25]. One gram of the fermented sample was mixed with $9 \mathrm{~mL}$ of saline water $(8.5 \mathrm{~g} / \mathrm{L}$ of $\mathrm{NaCl})$ and homogenized with a vortex. Serial decimal dilutions were performed and $0.1 \mathrm{~mL}$ of each dilution spread on MRS agar (yeast extract: $5 \mathrm{~g}$; meat extract: $5 \mathrm{~g}$; peptone: $10 \mathrm{~g}$; sodium acetate: $5 \mathrm{~g}$; sodium citrate: $2 \mathrm{~g}$; glucose: $20 \mathrm{~g}$; potassium phosphate: $2 \mathrm{~g}$; magnesium sulphate: $0.1 \mathrm{~g}$; manganese sulphate: $0.05 \mathrm{~g}$; agar: $15 \mathrm{~g}$; tween: $1 \mathrm{~mL}$ ), incubated for $24 \mathrm{~h}$ at $37^{\circ} \mathrm{C}$. Microbial loads were expressed as $\log 10$ colony-forming units (CFU) per gram of sample. 
2.6. Chemical, Physical and Functional Analyses of Flour. The fermented doughs were spread in a thin layer on a stainless steel tray and dried in a ventilated oven at $45^{\circ} \mathrm{C}$ for $24 \mathrm{~h}$, then ground in a hammer mill (Culatti, polymix, France), put in sterile bags in polyethylene, and stored at $4^{\circ} \mathrm{C}$ for further analysis. The analyses covered both fermented and unfermented flours.

\subsubsection{Determination of the Proximate Composition and Some} Phytochemicals. The flours were analyzed for dry matter and ash content [24]. The lipid content was determined by Soxhlet extraction using hexane according to the method described by Bourely [26], total sugar content was analyzed according to the Dubois method [27], and total protein $(N \times 6.25)$ was analyzed by the Devani et al. [28] method after sulfuric acid digestion using AACC method [29]. The crude fiber content was determined according to the method described by Hassan and Umar [30]. The caloric value of the flours expressed in $\mathrm{kcal} / 100 \mathrm{~g} \mathrm{DM}$ was determined using the Atwater values for fat $(9.0 \mathrm{kcal} / \mathrm{g})$, protein $(4.02 \mathrm{kcal} / \mathrm{g})$, and carbohydrates $(4.0 \mathrm{kcal} / \mathrm{g})$ as described by Kumar and Sharma [31]. Phenolic compounds, tannins, and phytates were determined using the method described by Marigo [32], Vaintraub and Lapteva [33], and Phillips et al. [34], respectively.

2.6.2. Physical and Functional Analyses of Flour. The colour parameters $L^{*}, a^{*}$, and $b^{*}$ (where $L^{*}$ is the lightness, $a^{*}$ the redness, and $b^{*}$ the yellowness) of the flours were measured using a tintometer (NH3R10, Nippon Denshoku Inc., Tokyo, Japan). A standard white plate $\left(L^{*}=93.87, a^{*}=0.18\right.$, and $b^{*}=2.72$ ) was used for the calibration before measurement.

The average size and the particle size distribution were determined with laser light scattering apparatus (Mastersizer S 2000, Malvern Instruments Ltd., Malvern, UK). The raw data from the optical unit is processed by the Sizer Sv2.17 software (Malvern Instrument, Orsay) to calculate the particle size.

The water absorption capacity and the solubility index of the flours were determined according to the method described by Phillips et al. [34]. The bulk density and the least gelling concentration (LGC) were determined using the method described by Okezie and Bello [35] and Coffmann and Garcia [36], respectively.

The pasting properties of suspensions with $10 \%$ dry matter were measured using a viscograph (VAN, Newport Scientific, Narrabeen, Australia). These suspensions were dispersed by stirring at $960 \mathrm{rpm}$ for $10 \mathrm{~s}$ then equilibrated at $50^{\circ} \mathrm{C}$ for $1 \mathrm{~min}$, heated at $6^{\circ} \mathrm{C} / \mathrm{min}$ to $95^{\circ} \mathrm{C}$, maintained at $95^{\circ} \mathrm{C}$ for $5 \mathrm{~min}$, and cooled from $95^{\circ} \mathrm{C}$ to $50^{\circ} \mathrm{C}$ at $6^{\circ} \mathrm{C} / \mathrm{min}$. During the analysis, the samples were continuously homogenized at $160 \mathrm{rpm}$. The pasting temperature $(\mathrm{Pt})$, peak viscosity (PV), final viscosity (FV), hot paste viscosity (HPV), setback (SB), and breakdown (BD) were calculated from the pasting curve using the Thermocline v. 3.15 software (Newport Scientific).

2.7. Statistical Analysis. The effect of fermentation and the mixture proportion on the physicochemical and functional properties of flours were evaluated using the analysis of variance. The Duncan test was used to evaluate the differences between means. The statistical analysis was performed using Statgraphics Centurion XV software, whereas the Sigma plot 11 software was used to draw curves.

\section{Results and Discussion}

3.1. $p H$, Titrable Acidity, and Bacterial Growing Kinetics during Fermentation. The effect of fermentation and flour proportion on $\mathrm{pH}$, titrable acidity, and bacterial growth was evaluated, and the results are presented in Figure 2.

The evolution of $\mathrm{pH}$ and titrable acidity were significantly $(p<0.05)$ affected by the proportion of flour in the mixture. Indeed, the $\mathrm{pH}$ was higher with the content of Bambara groundnut flour in the mixture and varied from 4.05 for the sample with $25 \%$ of Bambara groundnut (SVFP75) to 4.25 for the sample with $75 \%$ of Bambara groundnut flour (SVFP25), and at the same time, there was a decrease of titrable acidity with the increase of Bambara flour in the mixture. This evolution is due to the fact that Bambara groundnut is higher in protein content and makes it and the blend less acid than sorghum flour. Nevertheless, the $\mathrm{pH}$ remained below 5. During the first sixteen hours of fermentation, the $\mathrm{pH}$ of the samples significantly decreased from 6.40 to 4.80 in roasted and fermented Bambara groundnut (VFT100) and from 6.57 to 4.37 in precooked and fermented sorghum (SPF100). After this period, the $\mathrm{pH}$ of the samples remained almost constant with slight decrease from 3.85 to 3.59 for the mixture containing only precooked sorghum flour (SPF100). The decrease in $\mathrm{pH}$ of the samples may be mainly due to the production of the organic acids, showing the capacity of $L b$. plantarum A6 to ferment sugars in Bambara groundnut and sorghum flours as well as their mixture. Indeed, during the fermentation, the titrable acid measuring the total organic acid contents of the samples significantly $(p<0.05)$ increased from $0.11 \mathrm{mg} / \mathrm{g}$ lactic acid equivalent in the flour with $25 \%$ of sorghum (SVFP25) to $0.94 \mathrm{mg} / \mathrm{g}$ lactic acid equivalent after $40 \mathrm{~h}$. This result is similar to those obtained by Worku and Sahu [37] in the fermentation of red beans.

Figure 2(c) shows the growth of $L b$. plantarum A6 in the different samples. The bacterial load increased rapidly from 5 $\log \mathrm{CFU} / \mathrm{g}$ to $10 \mathrm{log} \mathrm{CFU} / \mathrm{g}$ after $20 \mathrm{~h}$ of fermentation, then remained constant until the sixtieth hour of fermentation and decreased up to $8.4 \mathrm{log} \mathrm{CFU} / \mathrm{g}$ and $8.5 \mathrm{log} \mathrm{CFU} / \mathrm{g}$ for VFT100 and SVFP25, respectively, at the end of the fermentation. The fast growth of the $L b$. plantarum A6 in the samples shows its good aptitude to growth on sorghum and Bambara groundnut flour pastes. Indeed, $L b$. plantarum has been found in many local fermented starchy products as one of the main natural fermenting bacteria [38]. The ability of L. plantarum A6 to ferment leguminous products had also been reported by Pahane et al. [39]. Nguyen et al. [8] have also reported similar results during the fermentation of gelatinized rice/soybean slurries.

3.2. Proximate Composition of Blended Flours. Table 1 shows the proximal composition of the different flours. The dry matter of the flours varies during the fermentation and 


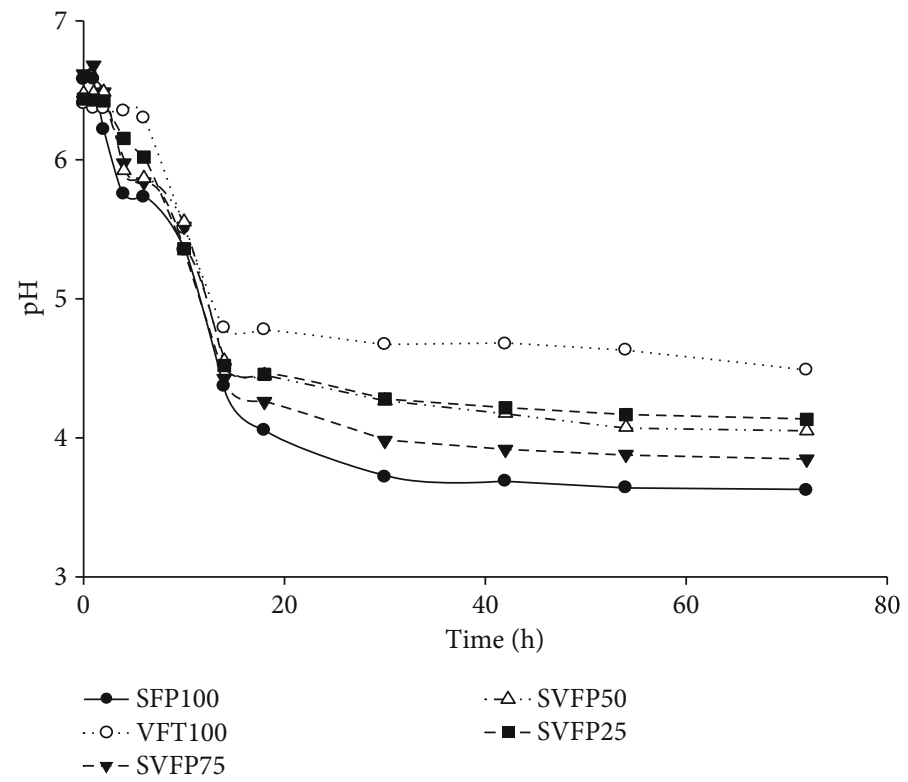

(a)

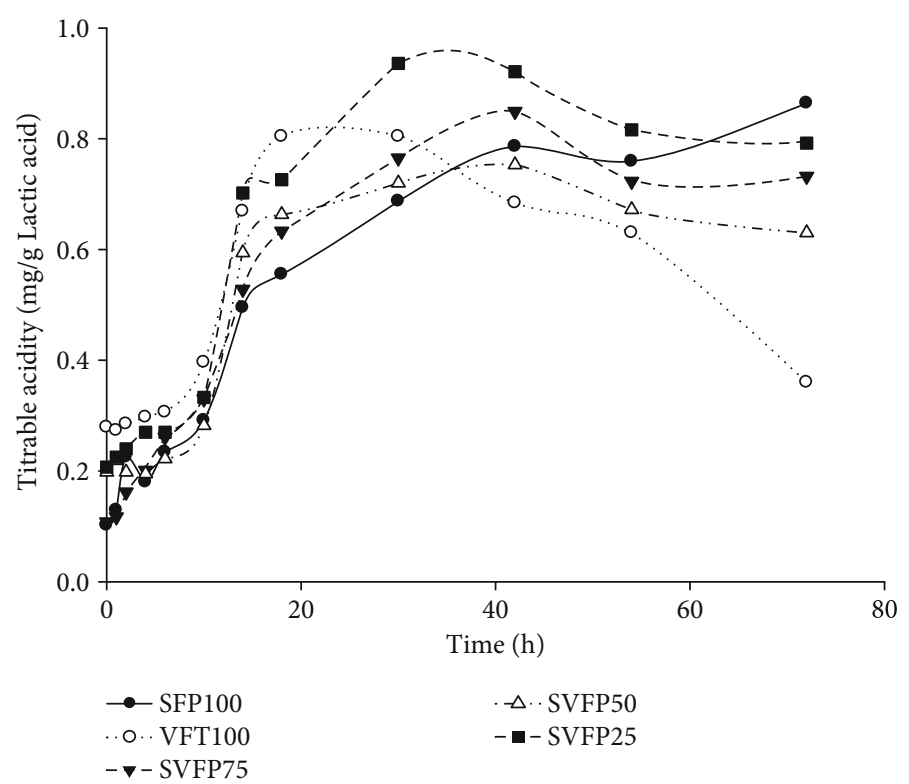

(b)

Figure 2: Continued. 


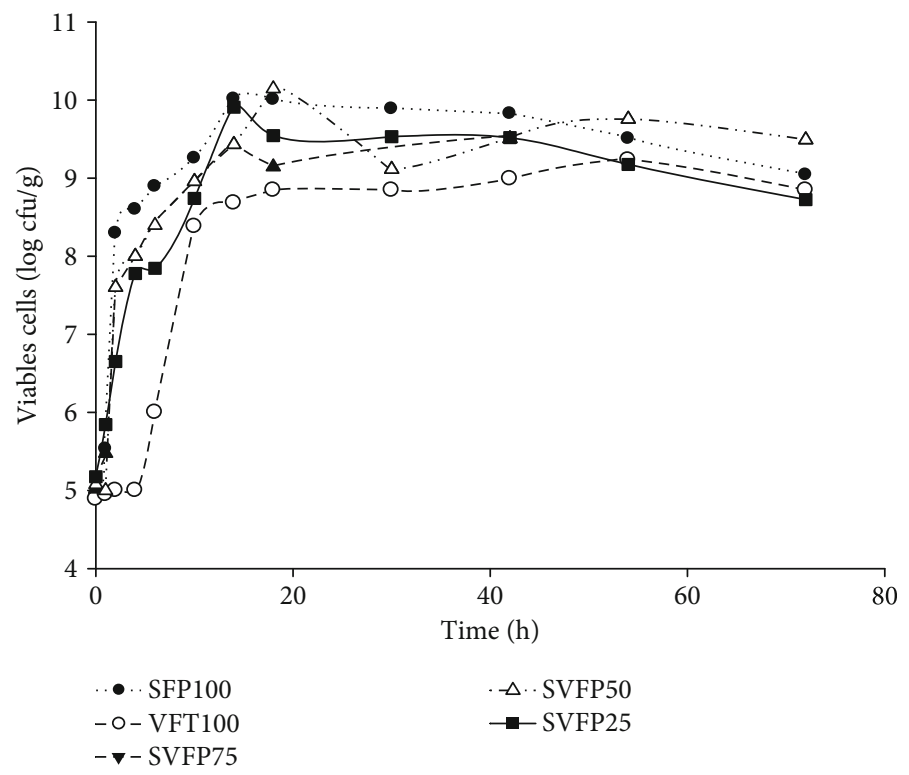

(c)

Figure 2: Evolution of pH (a), lactic acid (b), and L. plantarum A6 counts (c) during fermentation. SFP100: precooked and fermented sorghum flour; VFT100: roasted and fermented Bambara flour; SVFP25: fermented flour containing 25\% of precooked sorghum flour and 75\% roasted Bambara flour; SVFP50: fermented flour containing 50\% precooked sorghum flour and 50\% roasted Bambara flour; SVFP75: fermented flour containing $75 \%$ precooked sorghum flour $+25 \%$ roasted Bambara flour.

TABLE 1: Proximate composition of precooked fermented and unfermented flours.

\begin{tabular}{lccccccc}
\hline Samples & $\begin{array}{c}\text { Dry matter } \\
(\mathrm{g} / 100 \mathrm{~g} \mathrm{DM})\end{array}$ & $\begin{array}{c}\text { Ash } \\
(\mathrm{g} / 100 \mathrm{~g} \mathrm{DM})\end{array}$ & $\begin{array}{c}\text { Lipids } \\
(\mathrm{g} / 100 \mathrm{~g} \mathrm{DM})\end{array}$ & $\begin{array}{c}\text { Proteins } \\
(\mathrm{g} / 100 \mathrm{~g} \mathrm{DM})\end{array}$ & $\begin{array}{c}\text { Total sugars } \\
(\mathrm{g} / 100 \mathrm{~g} \mathrm{DM})\end{array}$ & $\begin{array}{c}\text { Crude fiber } \\
(\mathrm{g} / 100 \mathrm{~g} \mathrm{DM})\end{array}$ & $\begin{array}{c}\text { Energy } \\
(\mathrm{kcal} / 100 \mathrm{~g} \mathrm{DM})\end{array}$ \\
\hline SP & $91.23 \pm 0.47^{\mathrm{a}}$ & $2.59 \pm 0.02^{\mathrm{c}}$ & $3.55 \pm 0.08^{\mathrm{a}}$ & $12.10 \pm 0.06^{\mathrm{a}}$ & $70.28 \pm 0.46^{\mathrm{h}}$ & $1.70 \pm 0.25^{\mathrm{a}}$ & $368.43 \pm 0.12^{\mathrm{a}}$ \\
VT & $94.73 \pm 0.23^{\mathrm{e}}$ & $2.17 \pm 0.12^{\mathrm{b}}$ & $9.01 \pm 0.72^{\mathrm{f}}$ & $19.52 \pm 0.30^{\mathrm{g}}$ & $60.35 \pm 0.53^{\mathrm{a}}$ & $1.20 \pm 0.29^{\mathrm{a}}$ & $400.61 \pm 4.72^{\mathrm{e}}$ \\
SVP 25 & $95.6 \pm 0.20^{\mathrm{f}}$ & $2.27 \pm 0.21^{\mathrm{b}}$ & $7.23 \pm 0.54^{\mathrm{d}}$ & $18.42 \pm 0.24^{\mathrm{f}}$ & $62.76 \pm 0.39^{\mathrm{b}}$ & $1.40 \pm 0.52^{\mathrm{c}}$ & $389.79 \pm 3.87^{\mathrm{d}}$ \\
SVP 50 & $94.0 \pm 0.34^{\mathrm{d}}$ & $2.38 \pm 0.06^{\mathrm{b}}$ & $6.20 \pm 0.05^{\mathrm{c}}$ & $16.13 \pm 0.17^{\mathrm{d}}$ & $64.88 \pm 0.27^{\mathrm{e}}$ & $1.54 \pm 0.26^{\mathrm{c}}$ & $380.56 \pm 0.60^{\mathrm{c}}$ \\
SVP 75 & $93.13 \pm 0.23^{\mathrm{c}}$ & $2.48 \pm 0.22^{\mathrm{b}}$ & $5.14 \pm 0.04^{\mathrm{b}}$ & $14.20 \pm 0.11^{\mathrm{b}}$ & $67.58 \pm 0.23^{\mathrm{f}}$ & $1.76 \pm 0.33^{\mathrm{c}}$ & $373.38 \pm 0.90^{\mathrm{b}}$ \\
SVFP 25 & $94.53 \pm 0.64^{\mathrm{de}}$ & $1.86 \pm 0.05^{\mathrm{a}}$ & $8.15 \pm 0.15^{\mathrm{e}}$ & $19.98 \pm 0.30^{\mathrm{f}}$ & $60.66 \pm 0.07^{\mathrm{c}}$ & $2.09 \pm 0.45^{\mathrm{c}}$ & $395.95 \pm 1.62^{\mathrm{d}}$ \\
SVFP 50 & $92.13 \pm 0.23^{\mathrm{b}}$ & $2.20 \pm 0.27^{\mathrm{b}}$ & $6.46 \pm 0.07^{\mathrm{c}}$ & $17.91 \pm 0.25^{\mathrm{e}}$ & $62.51 \pm 0.32^{\mathrm{d}}$ & $2.23 \pm 0.35^{\mathrm{c}}$ & $376.22 \pm 2.64^{\mathrm{b}}$ \\
SVFP 75 & $94.0 \pm 0.40^{\mathrm{d}}$ & $2.91 \pm 0.22^{\mathrm{c}}$ & $5.47 \pm 0.36^{\mathrm{b}}$ & $15.88 \pm 0.20^{\mathrm{c}}$ & $64.37 \pm 0.17^{\mathrm{e}}$ & $2.52 \pm 0.49^{\mathrm{c}}$ & $370.23 \pm 1.49^{\mathrm{c}}$ \\
\hline
\end{tabular}

In the same column, the values followed by the same superscript letters are not significantly different $(p<0.05)$. SP: precooked dehulled sorghum flour; VT: roasted dehulled Bambara flour; SVP25: blended flour containing 25\% of precooked sorghum flour and 75\% of roasted Bambara flour; SVP50: blended flour containing 50\% of precooked sorghum flour and 50\% of roasted Bambara flour; SVP75: blended flour containing $75 \%$ of precooked sorghum flour and $25 \%$ of roasted Bambara flour; SVFP25: fermented flour containing 25\% of precooked sorghum flour and 75\% roasted Bambara flour; SVFP50: fermented flour containing 50\% precooked sorghum flour and 50\% roasted Bambara flour; SVFP75: fermented flour containing 75\% precooked sorghum flour and 25\% roasted Bambara flour.

decreases from $95.6 \%$ to $94.53 \%$ for SVP25 and from $94.0 \%$ to $92.13 \%$ for SVP50. This result shows that fermentation decreases the dry matter of flour, except in the case of SVP75, for which the fermentation leads to an increase in dry matter from $93.13 \%$ to $94.53 \%$. Fermentation would, therefore, cause changes in the chemical composition of flour. Moreover, dry matter also increases with an increase of Bambara groundnut proportion into the mixture from 93.13\% for the precooked and blended flour with $25 \%$ of Bambara groundnut (SVP75) to $95.6 \%$ for the precooked and blended flour with $75 \%$ of Bambara groundnut (SVP25).
The ash content of flours ranged from 2.27 to $2.48 \mathrm{~g} / 100 \mathrm{~g}$ $\mathrm{DM}$ in unfermented samples and 1.86 to $2.91 \mathrm{~g} / 100 \mathrm{~g} \mathrm{DM}$ in fermented blends (Table 1). In general, the ash content of the different flour was not significantly $(p>0.05)$ affected by the fermentation. These results are different to those reported by Oyarekua and Bankefa [40] who showed a decrease of ash content in cooked maize and walnut after fermentation as a result of usage of minerals by increased metabolic activities of inherent microorganisms. In the case of increasing the ash content of the SVP75 flour, similar results were also reported by Simwaka et al. [41] on the fermentation of 
pumpkin and amaranth blended flours at different proportions. However, the substitution of sorghum flour by Bambara groundnut flour mainly at $75 \%$ and $50 \%$ significantly $(p<0.05)$ decreased the ash content of the fermented blended flour and could be due to the low ash content of the Bambara groundnut precooked flour used (Table 1).

Fat content increased with the Bambara flour rate in the mixture and is due to its higher fat content compared to sorghum flour (Table 1). However, the fat content of the samples was not significantly $(p \leq 0.05)$ affected by fermentation. The fat content of SVP50 is $6.20 \mathrm{~g} / 100 \mathrm{~g} \mathrm{DM}$ and that of SVP75 is $5.14 \pm 0.04 \mathrm{~g} / 100 \mathrm{~g}$ DM. After fermentation of these flours, the fat content is $6.46 \mathrm{~g} / 100 \mathrm{~g} \mathrm{DM}$ and $5.45 \mathrm{~g} / 100 \mathrm{~g} \mathrm{DM}$, respectively, for SVFP50 and SVFP75. Thus, there would be no significant variation in the lipid content after fermentation. However, there was a slight increase of $0.92 \mathrm{~g} / 100 \mathrm{~g} \mathrm{DM}$ on the flour blend containing $75 \%$ Bambara groundnut, ranging from $7.23 \mathrm{~g} / 100 \mathrm{~g} \mathrm{DM}$ for SVP25 to $8.15 \mathrm{~g} / 100 \mathrm{~g}$ DM for SVFP25. This slight increase would be the result of the concentration of certain nutrients as a result of the reduction in sugar content since the fact that $L b$. plantarum metabolizes mainly sugar during the fermentation. This result differs from that has been found by Chinenye et al. [42] who reported the decrease of fat content in pearl millet flour after fermentation. This difference could be explained by the type of microorganism used for fermentation. Among the different samples, the fermented flour with $25 \%$ of sorghum and $75 \%$ of Bambara groundnut (SVFP25) having $8 \%$ of fat is suitable for use in complementary weaning food [4].

Protein contents increased with fermentation and the substitution rate. It is significantly and positively correlated to Bambara groundnut content and lies between $12.10 \%$ in precooked sorghum and $19.98 \%$ in fermented flour containing $75 \%$ of Bambara groundnut (SVFP25). This is attributed to high levels of protein content in Bambara groundnut. There is a slight increase in the protein content during fermentation and can be due to the activity of $L b$. plantarum A6 with the synthesis of new cells rich in protein while decreasing the carbohydrate content by fermentation. Ojokoh et al. [43] also reported improvement and protein content of food by fermentation.

The total sugar content of the samples ranged from $69.65 \%$ in SP to $60.35 \%$ in VT (Table 1). For the mixtures, the total sugar content decreased by up to $62.76 \%$ with the increase of the Bambara flour rate in the flour mixture (SVP25). This result could be explained by the lower total sugar content in the Bambara groundnut compared to that of sorghum flour. In general, the total sugar content of the fermented samples $(60.66,62.51$, and $64.37 \%$, respectively, for SVFP25, SVFP50, and SVFP75) is lower than that of unfermented flours $(62.76,64.88$, and $67.58 \%$, respectively, for SVP25, SVP50, and SVP75). The decrease in total sugar during fermentation is the fact of the utilization of sugars by Lactobacillus plantarum A6 for metabolic activities, mainly as an energy source [44]. The variation of fat, protein, and sugar content affects the caloric value of the samples (Table 1). The caloric values range from $363.04 \pm 1.91 \mathrm{kcal} /$ $100 \mathrm{~g} \mathrm{DM}$ in the unfermented sorghum flours (SP) to
TABLE 2: Antinutrient composition of precooked fermented and unfermented flours.

\begin{tabular}{lccc}
\hline Samples & $\begin{array}{c}\text { Total phenolic } \\
\text { compound } \\
(\mathrm{mg} / 100 \mathrm{~g} \mathrm{DM})\end{array}$ & $\begin{array}{c}\text { Tannins } \\
(\mathrm{mg} / 100 \mathrm{~g} \mathrm{DM})\end{array}$ & $\begin{array}{c}\text { Phytate } \\
(\mathrm{mg} / 100 \mathrm{~g} \mathrm{DM})\end{array}$ \\
\hline SP & $34.01 \pm 0.03^{\mathrm{b}}$ & $28.67 \pm 0.01^{\mathrm{b}}$ & $50.67 \pm 0.04^{\mathrm{b}}$ \\
VT & $138.01 \pm 0.09^{\mathrm{f}}$ & $57.33 \pm 0.03^{\mathrm{f}}$ & $166.53 \pm 0.013^{\mathrm{f}}$ \\
SVP 25 & $117.02 \pm 0.06^{\mathrm{e}}$ & $50.16 \pm 0.02^{\mathrm{e}}$ & $137.16 \pm 0.010^{\mathrm{e}}$ \\
SVP 50 & $96.03 \pm 0.03^{\mathrm{d}}$ & $43.01 \pm 0.02^{\mathrm{d}}$ & $108.33 \pm 0.08^{\mathrm{d}}$ \\
SVP 75 & $65.01 \pm 0.01^{\mathrm{c}}$ & $35.83 \pm 0.01^{\mathrm{c}}$ & $79.50 \pm 0.06^{\mathrm{c}}$ \\
SVFP 25 & $29.05 \pm 0.03^{\mathrm{ab}}$ & $11.41 \pm 0.01^{\mathrm{a}}$ & $41.17 \pm 0.03^{\mathrm{ab}}$ \\
SVFP 50 & $27.33 \pm 0.01^{\mathrm{ab}}$ & $11.15 \pm 0.01^{\mathrm{a}}$ & $35.01 \pm 0.01^{\mathrm{a}}$ \\
SVFP 75 & $25.16 \pm 0.027^{\mathrm{a}}$ & $11.58 \pm 0.01^{\mathrm{a}}$ & $28.83 \pm 0.01^{\mathrm{a}}$ \\
\hline
\end{tabular}

In the same column, the values followed by the same superscript letters are not significantly different $(p<0.05)$. SP: precooked dehulled sorghum flour; VT: roasted dehulled Bambara flour; SVP25: blended flour containing 25\% of precooked sorghum flour and $75 \%$ of roasted Bambara flour; SVP50: blended flour containing 50\% of precooked sorghum flour and $50 \%$ of roasted Bambara flour; SVP75: blended flour containing 75\% of precooked sorghum flour and 25\% of roasted Bambara flour; SVFP25: fermented flour containing $25 \%$ of precooked sorghum flour and $75 \%$ roasted Bambara flour; SVFP50: fermented flour containing 50\% precooked sorghum flour and 50\% roasted Bambara flour; SVFP75: fermented flour containing 75\% precooked sorghum flour and 25\% roasted Bambara flour.

$400.61 \pm 4.72 \mathrm{kcal} / 100 \mathrm{~g}$ DM in roasted Bambara flour (VT). Thus, the increase in the level of Bambara flour in the mixture significantly increased the caloric value of the sample. This is due to the higher caloric value of Bambara groundnut thanks to its high-fat content. There was a slight increase in the caloric value of the samples after fermentation as the fat and protein contents increased in these flour samples at the end fermentation process.

The crude fiber content of the samples was not significantly affected by the fermentation and varies from 1.76, 1.54 , and $1.40 \%$ in unfermented blended flour (SVP75, SVP50, and SVP25, respectively) to $2.52,2.23$, and $2.09 \%$ in fermented blended flour (SVFP75, SVFP50, and SVFP25, respectively) (Table 1). Different results were reported [45] with a significant reduction of the crude fiber content of sesame and melon after natural fermentation, and this could be attributed to microbial strains used.

3.3. Antinutrient Composition of Blended Flours. The results of the analysis on the antinutrient composition of the different flours are shown in Table 2. The total polyphenol content of the different flours produced decreased during fermentation, lying between $117.02 \mathrm{mg} / 100 \mathrm{~g} \mathrm{DM}$ in unfermented flour (SVP25) and $29.05 \mathrm{mg} / 100 \mathrm{~g} \mathrm{DM}$ after fermentation in SVFP25. The reduction in total polyphenol compounds could be related to the activity of the polyphenol oxidase of the microflora used for the fermentation [46]. Similar results were reported by Noumo et al. [44] using Lb. plantarum A6 for the fermentation of Moringa leaf powder. The ratio of the flours in the mixture also significantly influenced the polyphenol content of the samples. Indeed, the increase in 
TABLE 3: Colour of flours.

\begin{tabular}{lccc}
\hline Samples & $L^{*}$ & $a^{*}$ & $b^{*}$ \\
\hline SP & $78.65 \pm 0.98^{\mathrm{ab}}$ & $4.68 \pm 0.24^{\mathrm{a}}$ & $14.15 \pm 0.24^{\mathrm{a}}$ \\
VT & $84.59 \pm 5.21^{\mathrm{c}}$ & $7.96 \pm 4.01^{\mathrm{bc}}$ & $22.85 \pm 7.46^{\mathrm{bc}}$ \\
SVP 25 & $82.33 \pm 0.33^{\mathrm{bc}}$ & $9.20 \pm 0.24^{\mathrm{c}}$ & $25.71 \pm 0.63^{\mathrm{c}}$ \\
SVP 50 & $80.45 \pm 1.94^{\mathrm{ab}}$ & $8.23 \pm 0.60^{\mathrm{bc}}$ & $23.69 \pm 1.12^{\mathrm{bc}}$ \\
SVP 75 & $81.96 \pm 0.96^{\mathrm{bc}}$ & $6.16 \pm 0.18^{\mathrm{ab}}$ & $19.77 \pm 0.22^{\mathrm{b}}$ \\
SVFP 25 & $79.06 \pm 0.54^{\mathrm{ab}}$ & $9.22 \pm 0.07^{\mathrm{c}}$ & $23.07 \pm 0.21^{\mathrm{bc}}$ \\
SVFP 50 & $77.60 \pm 0.57^{\mathrm{a}}$ & $9.03 \pm 0.07^{\mathrm{c}}$ & $23.23 \pm 0.31^{\mathrm{bc}}$ \\
SVFP 75 & $76.70 \pm 1.08^{\mathrm{a}}$ & $8.41 \pm 0.24^{\mathrm{bc}}$ & $20.73 \pm 0.28^{\mathrm{bc}}$ \\
\hline
\end{tabular}

In the same column, the values followed by the same letters in exponent are not significantly different $(p<0.05)$. SP: precooked dehulled sorghum flour; VT: roasted dehulled Bambara flour; SVP25: blended flour containing 25\% of precooked sorghum flour and 75\% of roasted Bambara flour; SVP50: blended flour containing 50\% of precooked sorghum flour and $50 \%$ of roasted Bambara flour; SVP75: blended flour containing 75\% of precooked sorghum flour and $25 \%$ of roasted Bambara flour; SVFP25: fermented flour containing $25 \%$ of precooked sorghum flour and $75 \%$ roasted Bambara flour; SVFP50: fermented flour containing 50\% precooked sorghum flour and 50\% roasted Bambara flour; SVFP75: fermented flour containing $75 \%$ precooked sorghum flour and 25\% roasted Bambara flour.

the proportion of Bambara also increased the total polyphenol content of the flour mixture.

The fermentation of the flours induced a decrease in their tannin content from $50 \mathrm{mg} / 100 \mathrm{~g} \mathrm{DM}$ in SVP75 to $11 \mathrm{mg} / 100 \mathrm{~g} \mathrm{DM}$ in the fermented flours. There was no significant difference between the fermented flours regardless of the proportions of the mixtures. The reduction of total tannins could be due to the tannase activity of Lactobaccillus [47].

The phytate contents of the various flour samples are shown in Table 1. Globally, the fermentation reduced by $70 \%$ the phytates content of the mixture of precooked sorghum flour (25\%) and roasted Bambara flour (75\%). Also, the reduction of the proportion of Bambara in the mixture showed the reduction of total phytates content in the blends. The reduction of phytate content during fermentation could be attributed to the ability of $L b$. plantarum A6 to produce phytases [48]. Indeed, Noumo et al. [44] also reported the reduction of phytate contents in Moringa leaf powder during fermentation by Lb. plantarum A6.

Polyphenols, tannins, and phytates are known to reduce the availability of minerals such as iron and to bind to macromolecules such as proteins and carbohydrates, reducing their digestibility in foods [49]. Thus, by decreasing total phenolic compounds, tannins, and phytate content, the fermentation of the precooked Bambara groundnut flour, sorghum flour, and their mixture with $\mathrm{Lb}$. plantarum leads to the improvement of their nutritional quality.

\subsection{Physical, Functional, and Pasting Properties of Blended Flours}

3.4.1. Colour. The colour parameters $L^{*}, a^{*}$, and $b^{*}$ of treated samples are presented in Table 3 . Colour parameters are
TABLE 4: Particle size distribution parameters $(\mu \mathrm{m})$.

\begin{tabular}{lcccc}
\hline Samples & $\mathrm{d} 10$ & $\mathrm{~d} 50$ & $\mathrm{~d} 90$ & Means \\
\hline SP & 14.977 & 130.506 & 489.271 & 196.397 \\
VT & 18.465 & 62.814 & 235.002 & 98.745 \\
SVP 25 & 19.882 & 82.935 & 343.394 & 138.114 \\
SVP 50 & 22.461 & 117.385 & 342.531 & 165.363 \\
SVP 75 & 25.795 & 170.006 & 442.437 & 205.122 \\
SVFP 25 & 50.849 & 172.886 & 437.782 & 212.943 \\
SVFP 50 & 18.588 & 111.416 & 368.797 & 157.785 \\
SVFP 75 & 21.404 & 145.621 & 364.546 & 171.822
\end{tabular}

SP: precooked dehulled sorghum flour; VT: roasted dehulled Bambara flour; SVP25: blended flour containing $25 \%$ of precooked sorghum flour and $75 \%$ of roasted Bambara flour; SVP50: blended flour containing 50\% of precooked sorghum flour and $50 \%$ of roasted Bambara flour; SVP75: blended flour containing $75 \%$ of precooked sorghum flour and $25 \%$ of roasted Bambara flour; SVFP25: fermented flour containing 25\% of precooked sorghum flour and 75\% roasted Bambara flour; SVFP50: fermented flour containing $50 \%$ precooked sorghum flour and 50\% roasted Bambara flour; SVFP75: fermented flour containing $75 \%$ precooked sorghum flour and $25 \%$ roasted Bambara flour.

important criteria for the acceptability of food products. A lower $L^{*}$ value indicates a darker flour, a positive $a^{*}$ value is associated with redness, and a positive $b^{*}$ value indicates yellow colour. The sorghum and Bambara groundnut blended flours have whitish colour and good clarity, with high values of $L^{*}$ (82.23 (SVP25), 80.45 (SVP50), and 81.96 (SVP75)). The $L^{*}$ values decreased with fermentation up to 79.06 for SVFP25, 77.60 for SVFP50, and 76.70 for SVFP75. The decrease of $L^{*}$ value after fermentation could be due to the breakage of cell cytoplasm with the liberation of some pigmentation or to the enzymatic browning. Siddiqi et al. [50] reported that the fermentation of dough of whey protein reduces $L^{*}$ value. The $a^{*}$ and $b^{*}$ values of the samples increased with fermentation but were not influenced by the mixture proportion.

3.4.2. Particle Size Distribution. The effect of lactic fermentation and flour proportion on the particle size distribution of precooked flours is shown in Table 4. After fermentation, a significant reduction of the flour particle size was observed, from $205 \mu \mathrm{m}$ (SVP50) to $157 \mu \mathrm{m}$ (SVFP50) and from $212 \mu \mathrm{m}$ (SVP75) to $171 \mu \mathrm{m}$ (SVFP75). The size of the particles influenced the functional properties and the texture of the final product. The reduction of the particle size by fermentation can improve the smoothness of the gruel prepared with these flours. The fine particles of flour are important for fast hydration and cooking. Thus, these fermented flours used for the preparation of the gruel will require less time and energy for their hydration and cooking to that of unfermented flours. This result is similar to that of Oladeji [51], who showed that the particle size of unfermented maize was bigger than that of fermented samples. The high proportion of Bambara groundnut in the mixture also reduced the particle size of blended flours. This is because roasted Bambara groundnut has a smaller particle size $(98.745 \mu \mathrm{m})$ than precooked sorghum flour $(196.397 \mu \mathrm{m})$. 


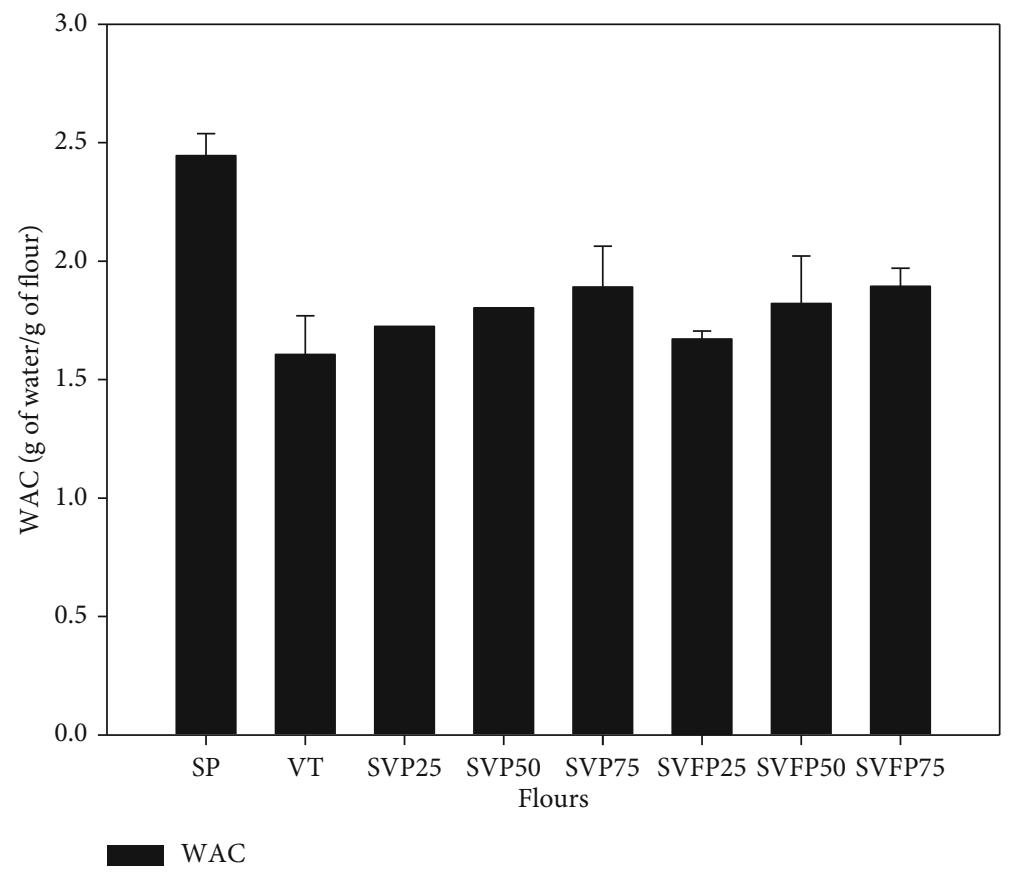

(a)

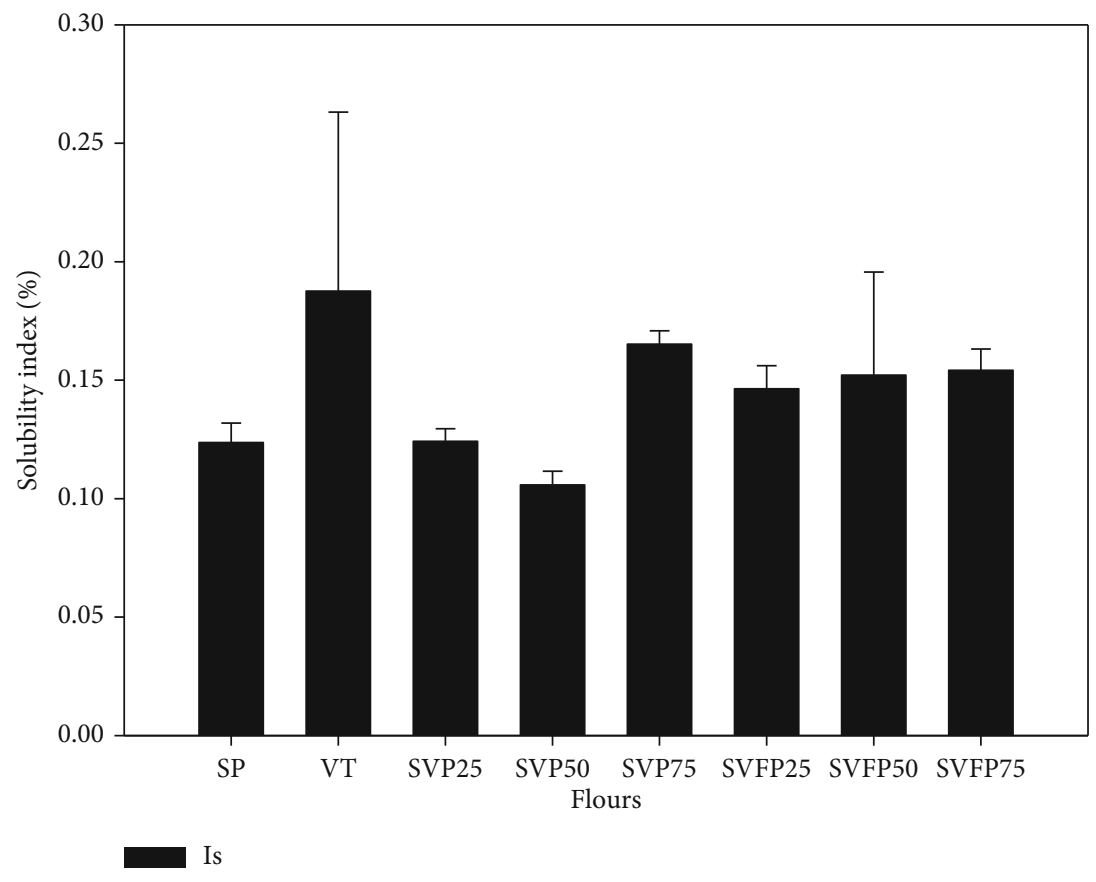

(b)

Figure 3: Continued. 


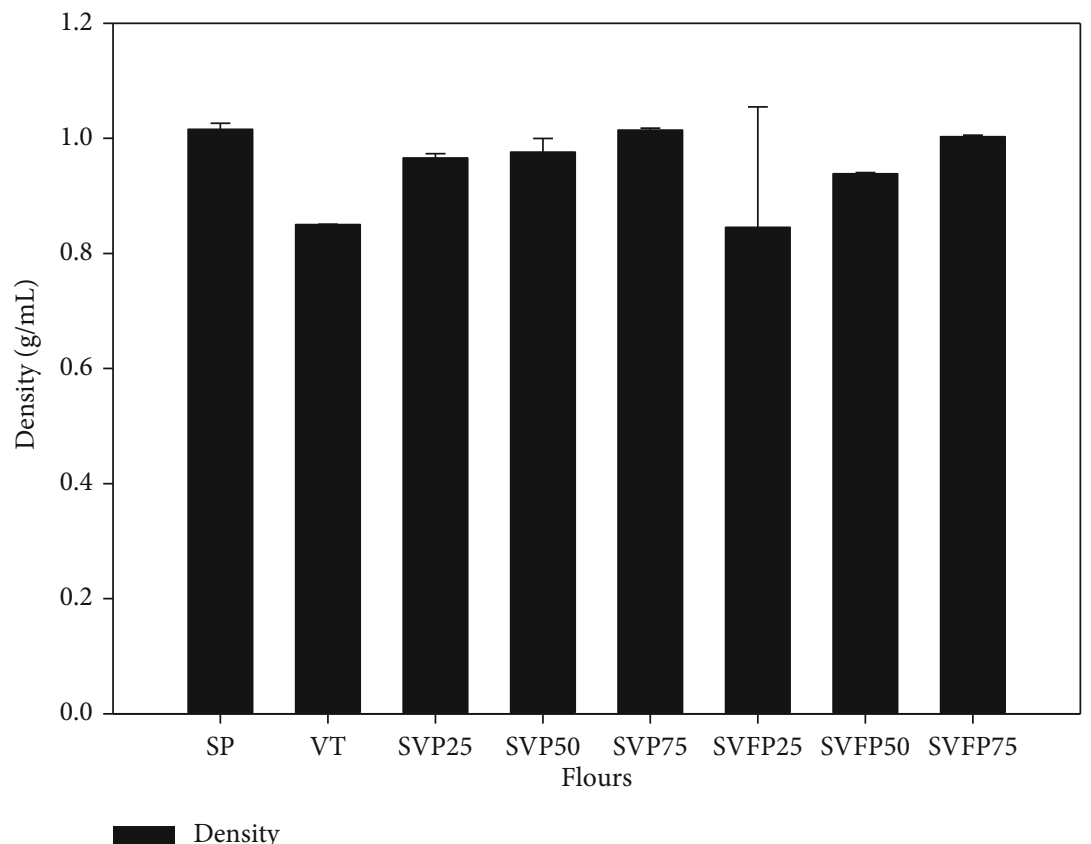

(c)

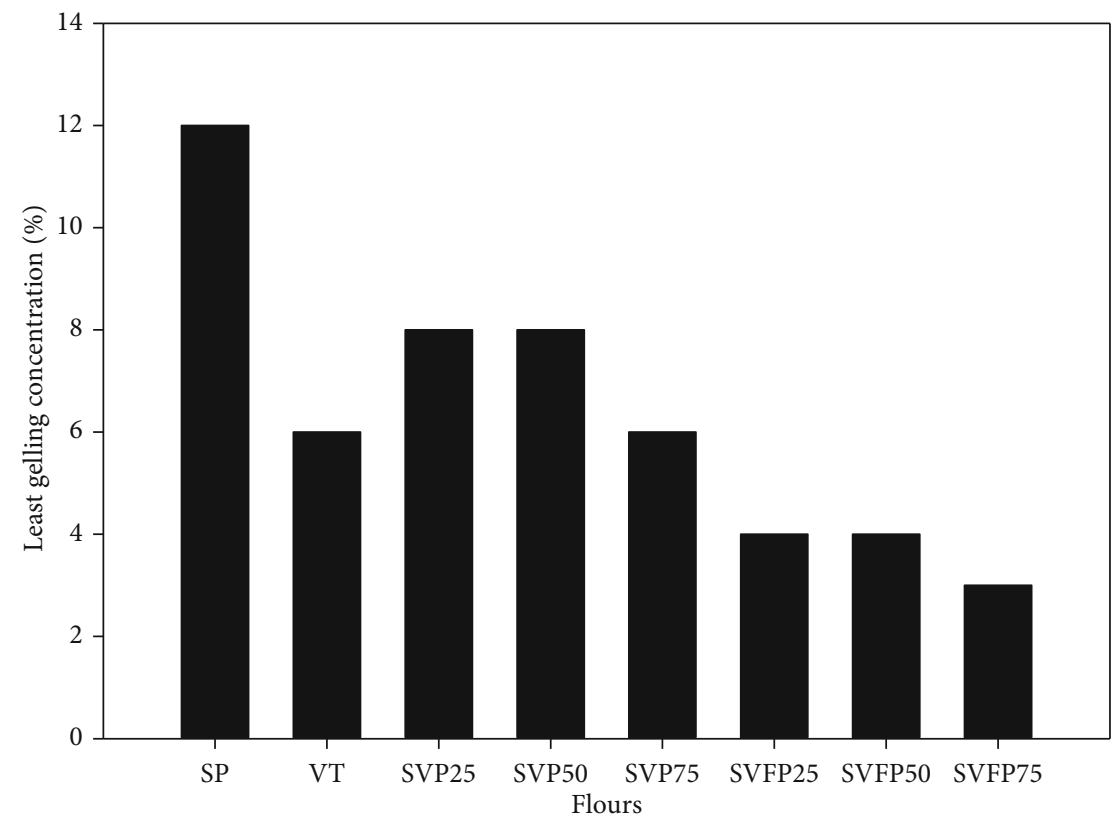

LGC

(d)

Figure 3: Water absorption capacity (a), solubility (b), density (c), and the least gelling concentration (d) of flours. SP: precooked dehulled sorghum flour; VT: roasted dehulled Bambara Flour; SVP25: blended flour containing 25\% of precooked sorghum flour and $75 \%$ of roasted Bambara flour; SVP50: blended flour containing 50\% of precooked sorghum flour and 50\% of roasted Bambara flour; SVP75: blended flour containing $75 \%$ of precooked sorghum flour and 25\% of roasted Bambara flour; SVFP25: fermented flour containing 25\% of precooked sorghum flour and 75\% roasted Bambara flour; SVFP50: fermented flour containing 50\% precooked sorghum flour and 50\% roasted Bambara flour; SVFP75: fermented flour containing 75\% precooked sorghum flour and 25\% roasted Bambara flour.

3.4.3. Functional Properties. The functional properties of food ingredients or raw materials play an important role in the formulation of food products. These functional properties influence the sensory properties, hence, consumer acceptability of food products. They include, in the case of infant flours, water absorption capacity, solubility, density, and least gelling concentration. The water absorption capacity, solubility index, density, and the least gelling concentration of the samples are presented in Figure 3. The fermentation of the mixtures SVFP25, SVFP50, and SVFP75 


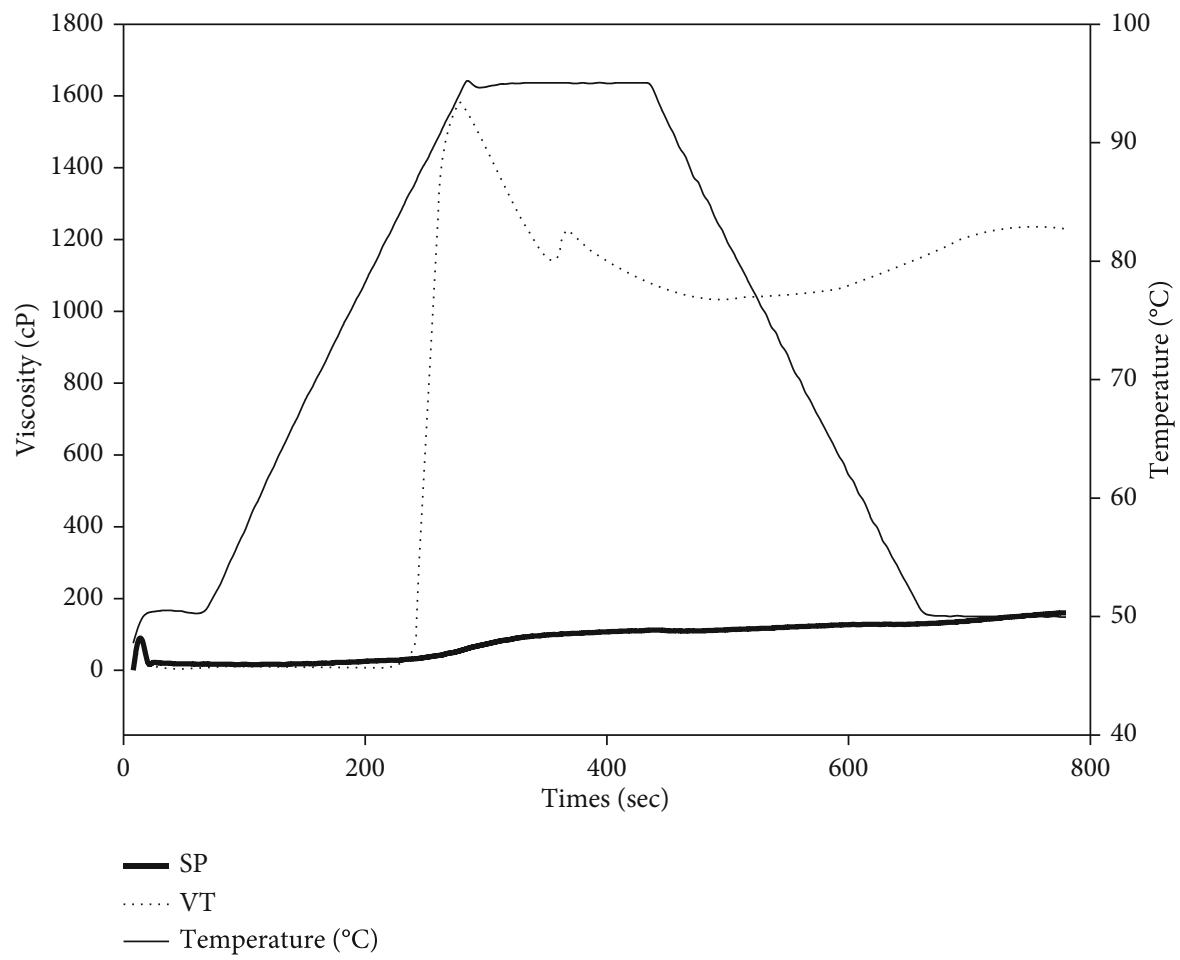

(a)

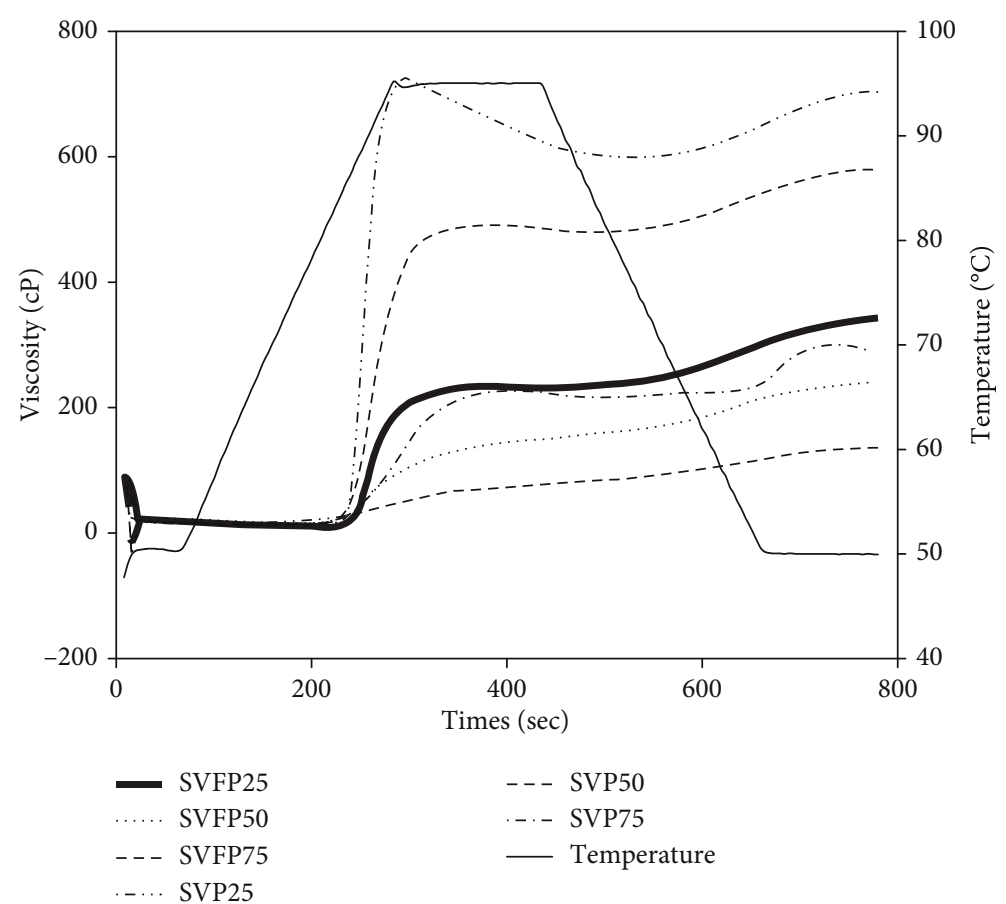

(b)

FIGURE 4: Pasting properties of precooked sorghum and Bambara groundnut flour (a) and blended precooked and fermented flour (b). SP: precooked dehulled sorghum flour; VT: roasted dehulled Bambara flour; SVP25: blended flour containing 25\% of precooked sorghum flour and 75\% of roasted Bambara flour; SVP50: blended flour containing 50\% of precooked sorghum flour and 50\% of roasted Bambara flour; SVP75: blended flour containing 75\% of precooked sorghum flour and 25\% of roasted Bambara flour; SVFP25: fermented flour containing 25\% of precooked sorghum flour and 75\% roasted Bambara flour; SVFP50: fermented flour containing 50\% precooked sorghum flour and 50\% roasted Bambara flour; SVFP75: fermented flour containing 75\% precooked sorghum flour and 25\% roasted Bambara flour. 
TABLE 5: Visco-analysis flours pasting profiles of fermented and unfermented flours.

\begin{tabular}{lcccccc}
\hline Samples & Peak (Pv) & Holding (HPV) & $\begin{array}{c}\text { RVA viscosity, cP } \\
\text { Breakdown (BD) }\end{array}$ & Final (FV) & Setback (SB) & Pasting temperature, ${ }^{\circ} \mathrm{C}\left(P_{\text {temp }}\right)$ \\
\hline SP & 112 & 109 & 3 & 158 & 49 & 76.20 \\
VT & 1585 & 1038 & 547 & 1235 & 197 & 86.79 \\
SVP25 & 726 & 598 & 128 & 704 & 106 & 85.75 \\
SVP50 & 491 & 479 & 12 & 579 & 100 & 85.52 \\
SVP75 & 226 & 217 & 9 & 290 & 73 & 85.15 \\
SVFP25 & 234 & 232 & 2 & 342 & 110 & 85.03 \\
SVFP50 & 134 & 133 & 1 & 240 & 107 & 84.93 \\
SVFP75 & 69 & 68 & 1 & 136 & 68 & 83.51 \\
\hline
\end{tabular}

SP: precooked dehulled sorghum flour; VT: roasted dehulled Bambara flour; SVP25: blended flour containing 25\% of precooked sorghum flour and 75\% of roasted Bambara flour; SVP50: blended flour containing 50\% of precooked sorghum flour and 50\% of roasted Bambara flour; SVP75: blended flour containing $75 \%$ of precooked sorghum flour and $25 \%$ of roasted Bambara flour; SVFP25: fermented flour containing $25 \%$ of precooked sorghum flour and 75\% roasted Bambara flour; SVFP50: fermented flour containing 50\% precooked sorghum flour and 50\% roasted Bambara flour; SVFP75: fermented flour containing $75 \%$ precooked sorghum flour and $25 \%$ roasted Bambara flour.

reduced their water absorption capacity from 1.6, 1.71, and $1.80 \mathrm{~g}$ of water/g of flour to $1.55,1.63$, and 1.79 , respectively. A similar observation has been reported by Ogodo et al. [52] on lactic acid bacteria fermented soybean flour. The reduction in water absorption capacity of an instant flour after fermentation is interesting as it can allow the preparation of gruels with low moisture content and high energetic density suitable for infant nutrition.

After the fermentation of the mixtures, there was a slight decrease in density of the samples with the highest value recorded with SVP75 $(1.01 \mathrm{~g} / \mathrm{mL})$ and the lowest value with SVFP25 $(0.84 \mathrm{~g} / \mathrm{mL})$. This reduction would probably be due to the breakage of the intermolecular link making the granules more porous and less dense. Jude-Ojei et al. [53] reported similar results on maize "Ogi" supplemented with fermented moringa seeds. Since the bulk density is highest in sorghum flour than in Bambara flour, it affects the bulk density of the mixture. In fact, when the sorghum precooked flour is added to the mixture, more is the bulk density of mixture.

The least gelling concentration (LGC) is shown in Figure 3(d). The incorporation of Bambara groundnut flour in the mixture decreased the LGC from $12 \%$ in precooked sorghum to $6 \%$ for the mixture containing $75 \%$ of Bambara groundnut flour. Fermentation also decreased the LGC up to $3 \%$ for SVFP75. The decrease of the LGC of fermented flours could be explained by the hydrolysis of starch by the amylases of $L b$. plantarum A6 [54]. This reduces the ability of starch molecules to form networks that trap water molecules and thus allow the preparation of fluid gruel with high dry matter. Indeed, the fermentation of blended precooked sorghum and Bambara groundnut flours increased their solubility index from $0.10 \%$ for SVP50 and $0.12 \%$ for SVP25 to $0.15 \%$ for SVFP25 and 0.17\% SVFP75. Ogodo et al. [52] and Rahma et al. [54] also reported a similar result after fermentation of soybean flour and Treculia africana, respectively.

3.4.4. Pasting Properties. Pasting properties showing the behavior of flours upon heating and cooling of fermented and unfermented samples are presented in Figure 4 and Table 5.

The pasting temperature $\left(P_{\text {temp }}\right)$ of unfermented samples (SVP25, SVP50, and SVP75) (Table 4) were 85.75, 85.52, and $85.15^{\circ} \mathrm{C}$ and are higher than the pasting temperature of fermented samples (SVFP25, SVFP50, and SVFP75) (85.03, 84.93 , and $\left.83.51^{\circ} \mathrm{C}\right)$. Fermentation reduced the minimum cooking temperature of blended flours, and the fermented flour can swell more quickly than unfermented flour. Peak viscosity $(\mathrm{Pv})$ denotes the water-holding capacity of flours, and the final viscosity (Fv) indicates the ability of the sample to form a viscous paste after cooking and cooling. The peak viscosity of unfermented flours was $726 \mathrm{cP}, 491 \mathrm{cP}$, and $226 \mathrm{cP}$ for SVP25, SVP50, and SVP75, respectively. These $\mathrm{Pv}$ values decreased after fermentation up to $234 \mathrm{cP}, 134 \mathrm{cP}$, and $69 \mathrm{cP}$ for SVFP25, SVFP50, and SVFP75, respectively. On the other hand, the final viscosity of unfermented flours was $726 \mathrm{cP}, 491 \mathrm{cP}$, and $226 \mathrm{cP}$ for SVP25, SVP50, and SVP75, respectively. $704 \mathrm{cP}, 579 \mathrm{cP}$, and $290 \mathrm{cP}$ for SVP25, SVP50, and SVP75, respectively. Similarly to Pv values, the Fv values decreased after fermentation up to $342 \mathrm{cP}, 240 \mathrm{cP}$, $136 \mathrm{cP}$ for SVP25, SVP50, and SVP75, respectively. This can be due to the unfolding of starch during precooking with the subsequent increase of its accessibility to the hydrolytic enzyme, bacterial amylase during fermentation. Similarly, Nago [55] showed a decrease in viscosity after the fermentation of "ogui." Nguyen et al. [8] reported that a combination of cooking and lactic fermentation considerably reduced the viscosity of the gruels prepared with rice and soybean blended flour. The peak viscosity also increased with a high level of Bambara groundnut flour in the mixture. This is due to the high protein contents in Bambara groundnut flour, which can gel during the cooking and contribute to increase the viscosity of the flour.

Hot paste viscosity (HPV) or holding strength indicates a shear-thinning property of the flour sample. It can be seen in Table 3 that roasted Bambara groundnut has a higher HPV $(1038 \mathrm{cP})$ than precooked sorghum $(109 \mathrm{cP})$ and the blended flours. This can be due to the resistance of its starch to shear 
stress and high temperature or the contribution of other components of its flours, mainly proteins, to the formation of heat-stable gel. When Bambara groundnut flour was mixed with sorghum flour, the HPV decreased significantly up to $598 \mathrm{cP}, 479 \mathrm{cP}$, and $217 \mathrm{cP}$ for SVP25, SVP50, and SVP75 samples, respectively. The fermentation also reduced significantly HPV; thus, these fermented flour can be used to prepare gruels with low viscosity and high caloric value. This is in line with the report of Akintayo et al. [56] suggesting that modification of processing techniques may help to reduce the viscosity of a gruel and that the lower the viscosity of a gruel, the better its suitability for infants. The breakdown (BD) of roasted Bambara groundnut flour $(547 \mathrm{cP})$ was about two hundred times higher than precooked sorghum flour $(3 \mathrm{cP})$. These may be due to the total gelatinization of sorghum starch during precooking. For the different mixtures, the $\mathrm{BD}$ decreased with the increase of the proportion of sorghum flour with $128 \mathrm{cP}$ for $25 \%$ sorghum (SVP25), $12 \mathrm{cP}$ for $50 \%$ (SVP50), and $9 \mathrm{cP}$ for $75 \%$ (SVP75). Lactic acid fermentation significantly decreased the breakdown of blended flours from $128 \mathrm{cP}$ (SVP25), $12 \mathrm{cP}$ (SVP50), and $9 \mathrm{cP}$ (SVP75) to $2 \mathrm{cP}$ (SVFP25), $1 \mathrm{cP}$ (SVFP50), and $1 \mathrm{cP}$ (SVFP75), respectively. However, fermentation did not significantly affect the setback (SB) of the samples; thus, the fermentation did not affect the viscosity of the gruel prepared with these flours after cooling.

\section{Conclusion}

To our knowledge, this study is the first that has established the effect of lactic fermentation on precooked sorghum and Bambara groundnut blended flours. It appears at the end of the study that lactic acid fermentation affected the chemical composition of the flours by improving protein content making it possible to increase the protein and energy intake in the nutrition of young children. On the other hand, when the flours are first precooked, fermentation further reduces the viscosity of the sorghum/Bambara groundnut flour mixtures; this will result in a fluid porridge but more dense in nutrients and energy necessary for the child's growth. The fermentation of precooked sorghum, Bambara groundnut flours, and their mixture using Lb. plantarum A6 also reduces antinutrients of complex proteins and minerals, making them more available for the infant's absorption. From the overall results, the fermented blended flour containing 25\% precooked sorghum flour and 75\% roasted Bambara flour (SVFP25) would seem to be a promising alternative as instant flour for young children's nutrition.

\section{Data Availability}

Data are available on request. To request the data, please contact Pr. Leopold NGOUNE TATSADJIEU, University Institute of Technology, Department of Food Engineering and Quality Control, University of Ngaoundere, P.O Box 454 Ngaoundere, Cameroon; Cameroon tatsadjieu@yahoo.fr; Tel.: +237 699523727 .

\section{Conflicts of Interest}

The authors declare that they have no conflicts of interest.

\section{Authors' Contributions}

T.M.B.N. collected the samples and carried out experiments. B.A.M. reviewed and edited the paper. A.T.S. contributed to paper writing. N.Y.N. and L.N.T. supervised the work. All the authors have read and approved the manuscript.

\section{Acknowledgments}

We extend our sincere thanks to the Bioprocesses Laboratory of the University Institute of Technology, University of Ngaoundere, for providing us with the reagents and equipment necessary to carry out this work.

\section{References}

[1] FAO, FIDA, OMS, PAM, and UNICEF, L'État de la sécurité alimentaire et de la nutrition dans le monde: renforcer la résilience pour favoriser la paix et la sécurité alimentaire, Rome Italy, 2017.

[2] WHO, Complementary Feeding of Young Children in Developing Countries: A Review of Current Scientific Knowledge, World Health Organization; Geneva, 1998.

[3] P. Sen, A. Mardinogulu, and J. Nielsen, "Selection of complementary foods based on optimal nutritional values," Scientific Reports, vol. 7, no. 1, pp. 1-9, 2017.

[4] WHO, Guiding Principle for Complementary Feeding of the Breastfed Child, Pan American Health Organization, American Health Organization, Washington DC, USA, 2003.

[5] S. Trèche, O. Legros, and F. Tchibindat, Vitdort : un atelier pilote de fabrication de farine de sevrage à base de manioc au Congo, T. A. Egbe, A. Brauman, D. Griffon, and S. Trèche, Eds., ORSTOM, France, 1995.

[6] C. Mouquet, B. Salvignol, N. Van Hoan, J. Monvois, and S. Trèche, "Ability of a "very low-cost extruder" to produce instant infant flours at a small scale in Vietnam," Food Chemistry, vol. 82, no. 2, pp. 249-255, 2003.

[7] A. I. Sanni, J. Morlon-Guyot, and J. P. Guyot, "New efficient amylase-producing strains of Lactobacillus plantarum and $L$. fermentum isolated from different Nigerian traditional fermented foods," International Journal of Food Microbiology, vol. 72, no. 1-2, pp. 53-62, 2002.

[8] T. T. T. Nguyen, G. Loiseau, C. Icard-Vernière, I. Rochette, S. Trèche, and J.-P. Guyot, "Effect of fermentation by amylolytic lactic acid bacteria, in process combinations, on characteristics of rice/soybean slurries: a new method for preparing high energy density complementary foods for young children," Food Chemistry, vol. 100, no. 2, pp. 623-631, 2007.

[9] W. H. Holzapfel, "Appropriate starter culture technologies for small-scale fermentation in developing countries," International Journal of Food Microbiology, vol. 75, no. 3, pp. 197212, 2002.

[10] Y. Motarjemi, "Impact of small scale fermentation technology on food safety in developing countries," International Journal of Food Microbiology, vol. 75, no. 3, pp. 213-229, 2002.

[11] E. H. Tou, J. P. Guyot, C. Mouquet-Rivier et al., "Study through surveys and fermentation kinetics of the traditional 
processing of pearl millet (Pennisetum glaucum) into bensaalga, a fermented gruel from Burkina Faso," International Journal of Food Microbiology, vol. 106, no. 1, pp. 52-60, 2006.

[12] L. T. Songré-Ouattara, C. Mouquet-Rivier, C. Icard-Vernière, C. Humblot, B. Diawara, and J. P. Guyot, "Enzyme activities of lactic acid bacteria from a pearl millet fermented gruel (ben-saalga) of functional interest in nutrition," International Journal of Food Microbiology, vol. 128, no. 2, pp. 395-400, 2008.

[13] J. Haydersah, I. Chevallier, I. Rochette et al., "Fermentation by Amylolytic Lactic Acid Bacteria and Consequences for Starch Digestibility of Plantain, Breadfruit, and Sweet Potato Flours," Journal of Food Science, vol. 77, no. 8, pp. 66-72, 2007.

[14] N. R. Dlamini, L. Dykes, L. W. Rooney, R. D. Waniska, and J. R. N. Taylor, "Condensed tannins in traditional wetcooked and modern extrusion-cooked sorghum porridges," Cereal Chemistry Journal, vol. 86, no. 2, pp. 191-196, 2009.

[15] P. S. Belton and J. R. N. Taylor, "Sorghum and millets: protein sources for Africa," Trends in Food Science \& Technology, vol. 15, no. 2, pp. 94-98, 2004.

[16] C. H. Mkandawire, "Review of Bambara groundnut production in Sub-Saharan Africa," Agricultural Journal, vol. 2, no. 4, pp. 464-470, 2007.

[17] Agri-Stat Cameroun, Annuaire des statistiques du secteur agricole. Direction des enquêtes et statistiques agricoles, Cameroun, 2012.

[18] A. R. Linnemann, Cultivation of bambara groundnut (Vigna subterranea (L.) Verdc.) in Western Province, Zambia, Wageningen Agricultural University, 1990.

[19] M. Brink and G. Belay, Sources végétales de l'Afrique tropicale 1. Céréales et légumes secs, Fondation PROTA : CTA ; Backhuys Publishers, Wageningen; Leiden, Pays-Bas, 2004.

[20] G. Jiddere and B. F. Kalep, "The effect of feed moisture and barrel temperature on the essential amino acids profile of sorghum malt and bambara groundnut based extrudates," Journal of Food Processing \& Technology, vol. 6, no. 5, pp. 1-6, 2015.

[21] I. A. Onimawo, A. H. Momoh, and A. Usman, "Proximate composition and functional properties of four cultivars of bambara groundnut (Voandezeia subterranea)," Plant Foods for Human Nutrition, vol. 53, pp. 153-158, 1998.

[22] A. K. Arise, O. O. Akintayo, A. O. Dauda, and B. A. Adeleke, "Chemical, functional and sensory qualities of abari (maizebased pudding) nutritionally improved with bambara groundnut (Vigna subterranea)," Ife Journal of Science, vol. 21, no. 1, pp. 165-173, 2019.

[23] F. Ofori, S. Hahn, and K. Hahn, International Society for Tropical Root Crops. Proceedings of the Ninth Symposium of the International Society for Tropical Root Crops: Held at Accra, Ghana, 20-26 October 1991, International Society for Horticultural Science, Wageningen, Netherlands, 1994.

[24] AOAC, Official Methods of Analysis, Kenneth Helrich, Virginia-USA, 15th Ed. edition, 1990.

[25] H. Leclerc, J.-L. Gaillard, and M. Simonet, Microbiologie générale: la bactérie et le monde bactérien, Doin, (C1995, Paris, 4th Ed edition, 1995.

[26] J. Bourely, "Observation sur le dosage de l'huile des graines de cotonnier," Coton et Fibres Tropicales, vol. 27, pp. 183-196, 1982.

[27] M. Dubois, K. A. Gilles, J. K. Hamilton, and P. A. Rebers, "Colorimetric method for determination of sugars and related sub- stances," Analytical Chemistry, vol. 28, no. 3, pp. 350-356, 1956.

[28] M. B. Devani, C. J. Shishoo, S. A. Shah, and B. N. Suhagia, "Spectrophotometric method for the determination of nitrogen in Kjeldahl digests," Journal - Association of Official Analytical Chemists, vol. 72, no. 6, pp. 953-956, 1989.

[29] AACC, Approved Methods of the AACC, The Association, St. Paul, MN, USA, USA, 10th Edition edition, 2000.

[30] L. G. Hassan and K. J. Umar, "Nutritional value of balsam apple (Momordica balsamina L.) leaves," Pakistan Journal of Nutrition, vol. 5, no. 6, pp. 522-529, 2006.

[31] B. R. Phani Kumar and R. S. Sharma, "Effect of fly ash on engineering properties of expansive soils," Journal of Geotechnical and Geoenvironmental Engineering, vol. 130, no. 7, pp. 764767, 2004.

[32] G. Marigo, "Méthode de fractionnement et d'estimation des composes phénoliques chez les végétaux," Analysis, vol. 2, no. 2, pp. 106-110, 1973.

[33] I. A. Vaintraub and N. A. Lapteva, "Colorimetric determination of phytate in unpurified extracts of seeds and the products of their processing," Analytical Biochemistry, vol. 175, no. 1, pp. 227-230, 1988.

[34] R. D. Phillips, M. S. Chinnan, A. L. Branch, J. Miller, and K. H. McWatters, "Effects of pretreatment on functional and nutritional properties of cowpea meal," Journal of Food Science, vol. 53, no. 3, pp. 805-809, 1988.

[35] B. O. Okezie and A. B. Bello, "Physicochemical and functional properties of winged bean flour and isolate compared with soy isolate," Journal of Food Science, vol. 53, no. 2, pp. 450-454, 1988.

[36] C. W. Coffmann and V. V. Garciaj, "Functional properties and amino acid content of a protein isolate from mung bean flour*," International Journal of Food Science \& Technology, vol. 12 , no. 5, pp. 473-484, 1977.

[37] A. Worku and O. Sahu, "Significance of fermentation process on biochemical properties of Phaseolus vulgaris (red beans)," Biotechnology Reports, vol. 16, pp. 5-11, 2017.

[38] D. R. Djouldé, F.-X. Etoa, J.-J. Essia Ngang, and C. M. F. Mbofung, "Screening des microorganismes à potentialités fermentaires pour le manioc," Tropicultura, vol. 23, no. 1, pp. 1118, 2005.

[39] M. M. Pahane, L. N. Tatsadjieu, C. Bernard, and N. Y. Njintang, "Production, nutritional and biological value of bambara groundnut (Vigna subterranea) milk and yoghurt," Journal of Food Measurement and Characterization, vol. 11, no. 4, pp. 1613-1622, 2017.

[40] A. M. Oyarekua and O. E. Bankefa, "The effect of cooking and fermentation on the functional and nutritional properties of walnut and maize," International Journal of Nutrition and Food Sciences, vol. 4, no. 3, pp. 332-342, 2015.

[41] J. E. Simwaka, M. V. M. Chamba, Z. Huiming, K. G. Masamba, and Y. Luo, "Effect of fermentation on physicochemical and antinutritional factors of complementary foods from millet, sorghum, pumpkin and amaranth seed flours," International Food Research Journal, vol. 24, no. 5, pp. 18691879, 2017.

[42] E. O. Chinenye, A. O. Ayodeji, and J. A. Baba, "Effect of fermentation (natural and starter) on the physicochemical, antinutritional and proximate composition of pearl millet used for flour production," American Journal of Bioscience and Bioengineering, vol. 5, no. 1, pp. 12-16, 2017. 
[43] A. O. Ojokoh, M. K. Daramola, and O. J. Oluoti, "Effect of fermentation on nutrient and anti-nutrient composition of breadfruit (Treculia africana) and cowpea (Vigna unguiculata) blend flours," African Journal of Agricultural Research, vol. 8, no. 27, pp. 3566-3570, 2013.

[44] N. T. Noumo, N. L. Tatsadjieu, D. Montet, and C. M. F. Mbofung, "Effect of pure culture fermentation on biochemical composition of Moringa oleifera Lam leaves powders," Food and Nutrition Sciences, vol. 4, no. 8, pp. 851-859, 2013.

[45] E. O. Ibukun and O. J. Anyasi, "Changes in antinutrient and nutritional values of fermented sesame (Sesanum indicum), musk melon (Cucumis melo) and white melon (Cucumeropsis mannii)," International Journal of Advanced Biotechnology and Research, vol. 4, no. 1, pp. 131-141, 2013.

[46] N. Dhankher and B. M. Chauhan, "Effect of temperature and fermentation time on phytic acid and polyphenol content of rabadi-fermented peal millet food," Journal of Food Science, vol. 52, no. 3, pp. 828-829, 1987.

[47] A. O. E. Elkhalifa, B. Schiffler, and R. Bernhardt, "Effect of fermentation on the functional properties of sorghum flour," Food Chemistry, vol. 92, no. 1, pp. 1-5, 2005.

[48] M. Zamudio, A. Gonzalez, and J. A. Medina, "Lactobacillus plantarum phytase activity is due to non-specific acid phosphatase," Letters in Applied Microbiology, vol. 32, no. 3, pp. 181-184, 2001.

[49] L. R. Ferguson, "Role of plant polyphenols in genomic stability," Mutation Research/Fundamental and Molecular Mechanisms of Mutagenesis, vol. 475, no. 1-2, pp. 89-111, 2001.

[50] R. A. Siddiqi, D. S. Sogi, and P. K. Sehajpal, "Effect of shortterm sourdough fermentation on wheat protein," Cogent Food \& Agriculture, vol. 2, no. 1, pp. 1-10, 2016.

[51] B. S. Oladeji, "Assessment of physico-chemical properties, pasting profiles and sensory scores of co-processed quality protein maize and carrot complementary food," Journal of Advancements in Food Technology, vol. 1, no. 1, pp. 1-8, 2018.

[52] A. C. Ogodo, O. C. Ugbogu, and R. A. Onyeagba, "Variations in the functional properties of soybean flour fermented with lactic acid bacteria (LAB)-consortium," Applied Microbiology: Open Access, vol. 4, no. 1, pp. 1-6, 2018.

[53] B. S. Jude-Ojei, A. Lola, I. O. Ajayi, and S. Ilemobayo, "Functional and pasting properties of maize 'ogi' supplemented with fermented moringa seeds," Journal of Food Processing \& Technology, vol. 8, no. 5, pp. 1-4, 2017.

[54] I. N. Rahma, R. H. Pratama, D. R. A. Alfiyanti, W. I. S. T. Astuti, and D. H. Wardhani, "Swelling power and solubility of modified breadfruit flour using Lactobacillus plantarum," Journal of Physics: Conference Series, vol. 909, pp. 1-7, 2017.

[55] NAGO and COFFI, La transformation alimentaire traditionnelle du mais au Benin : détermination des caractéristiques physico-chimiques des variétés en usage; relations avec l'obtention et la qualité des principaux produits dérives [Ph.D. thesis], vol. 7, 1997.

[56] O. A. Akintayo, Y. O. Hashim, A. G. Adereti et al., "Potentials of rice as a suitable alternative for the production of Ogi (a cereal-based starchy fermented gruel)," Journal of Food Science, vol. 85, no. 8, pp. 2380-2388, 2020. 